\title{
Classroom Interaction Practices and Students' Learning Outcomes in Physics: Implication for Teaching-Skill Development for Physics Teachers
}

\author{
Emmanuel E. Achor ${ }^{\star}$ \\ Ibrahim M. Danjuma ${ }^{2}$ \\ Agaptus B. C. Orji ${ }^{3}$
}

Department of Curriculum \& Teaching, Benue State University, Makurdi Nigeria Email:nuelachor@yahoo.com Tel: +2348035157702

Department of Science Education, Abubakar Tafawa Balewa University, Bauchi Nigeria Email:imdanjuma@gmail.com Tel: +2348069250108

${ }^{3}$ Department of Environmental \&' Science Education, University of Abuja, Abuja Nigeria Email:agaptusorji@gmail.com Tel: +2347035029999

\begin{abstract}
In the last decade, evidence in the science education literature seems to suggest that studentcentered classroom interaction appears to have effect over and above teacher-centered interaction in enhancing learning outcomes in various science subjects especially in Physics. Based on this premise, this paper examined the effects of teacher-centered and student-centered interaction practices on students' achievement and attitude in dynamics, an aspect of Physics considered abstract at the secondary school level. This study employed both the quasi-experimental and observational survey designs. From a sample of four comparable schools in Kogi East Local Government Areas of Kogi State, Nigeria, 139 physics students from intact classes and seven teachers (4 who did the teaching and 3 others who observed in all classes) were involved in the study. Three instruments developed were used for data collection. These are Teacher-Student Classroom Observation Schedule (TSCOS), Students' Attitude Questionnaire (SAQ), and Physics Achievement Test (PAT) with reliability indices of $0.68,0.86$ and 0.79 respectively. The data generated from the use of the instruments were analyzed using descriptive statistics of mean and standard deviation to answer the research questions, while the ANCOVA statistic was used to test the hypotheses at $0.05 \alpha$-level. Results revealed that the difference between the mean performances and mean attitude of students exposed to the two types of interactions were statistically significant. Gender differences in mean performance and attitude scores were not significant. It was recommended that student-centered classroom interaction strategy should be advocated for use. Implications were drawn for teacher skills acquisition.
\end{abstract}

Keywords: Classroom interaction, Abstract concepts in physcis, Physics performance, Teacher-centered interaction, Students' attitude, Dynamics, Teaching skill development

Citation | Emmanuel E. Achor; Ibrahim M. Danjuma; Agaptus B. C. Orji (2019). Classroom Interaction Practices and Students' Learning Outcomes in Physics: Implication for Teaching-Skill Development for Physics Teachers. Journal of Education and eLearning Research, 6(3): 96-106.

History:

Received: 5 March 2019

Revised: 3 April 2019

Accepted: 10 May 2019

Published: 23 July 9019

Licensed: This work is licensed under a Creative Commons

Attribution 3.0 License (c))

Publisher: Asian Online Journal Publishing Group
Acknowledgement: All authors contributed to the conception and design of the study.

Funding: This study received no specific financial support.

Competing Interests: The authors declare that they have no conflict of interests.

Transparency: The authors confirm that the manuscript is an honest, accurate, and transparent account of the study was reported; that no vital features of the study have been omitted; and that any discrepancies from the study as planned have been explained.

Ethical: This study follows all ethical practices during writing.

\section{Contents}

1. Introduction

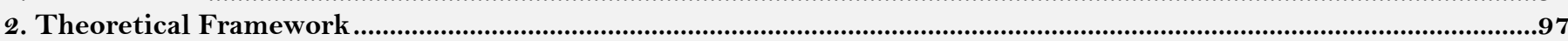

3. Methodology

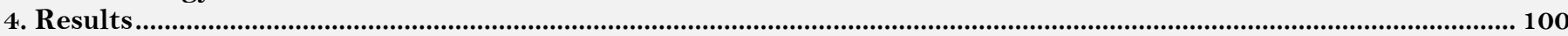

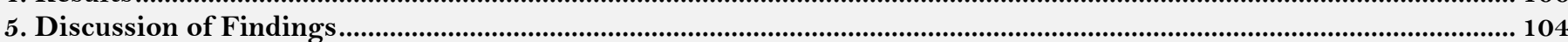

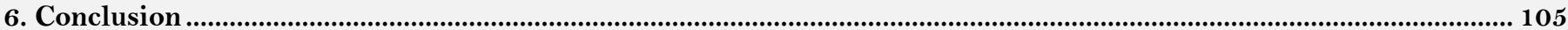

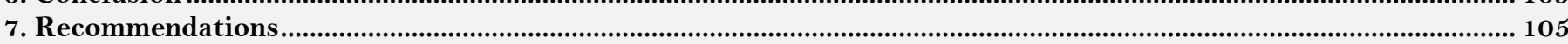

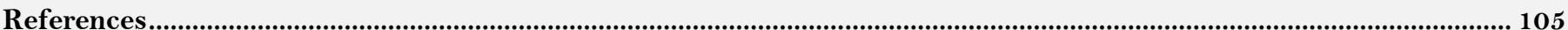




\section{Contribution of this paper to the literature}

This study contributes in the literature by scrutinizing the effects of teacher-centered and studentcentered interaction practices on students' achievement and attitude in dynamics, an aspect of Physics considered abstract at the secondary school level.

\section{Introduction}

In the last two decades, there have been numerous reports concerning the crisis in science education in general and physics in particular in the developing countries including Nigeria (Ajagun, 2007). According to West Africa Examination Council (WAEC) (2007) only ten percent of the candidates passed physics at credit level. Also, as reported by National Examination Council (NECO) (2007) an insignificant number (five percent) was able to pass physics at credit level. However, observers maintained that a more important factor responsible for the poor performance of students in Physics is related to the fact that teaching and learning environments in our school are not adequately characterized by teacher-student interaction processes.

Audu and Achor (2003) state that interaction in the classroom entails an active encounter of the teacher and the students through verbal, gestural and resource instrumentality to bring about effective communication in a teaching learning process. It involves techniques consisting of objective and systematic observation of the classroom events for the study of the teacher's classroom events and the process of interaction going on inside the classrooms. Interaction between teacher and students is a fundamental part of the teaching-learning process used in Physics. It not only guides teaching but could also aid in positive students' achievement and attitude towards Physics.

Recognition of the benefits that accrue to students when instruction is more student-centered and less teacherdirected has been widely reported (Freedman, 1997). This involves creating a learning environment in which students are encouraged to be actively involved and to accept responsibility for their own learning as well as creating a learning environment that focus attention not only on the condition under which learning occurs but also on the variables that mediate the teaching-learning process. Teacher-centered interaction was said not to provide a learning environment that allows students to be actively involved and to take responsibility for their own learning rather than remain passive during the teaching-learning process. To date, those employing interaction as means of teaching have employed a variety of approaches to structure learning. These varieties of approach adapted to structure learning include: cooperative classroom interaction, friendly classroom interaction, teachers' classroom management interaction, and so on.

Friendly classroom interaction entails a teaching-learning environment where students are allowed to exercise some control over their own learning. In this way, they are more likely to value the importance of achievementrelated behaviour and to demonstrate more internal motivation with their school work. Management of classroom interaction includes controlled or formalized classroom behaviour, clarified classroom or individual goal, developed subject contents and reinforced students' behaviour. The level of difficulty of the subject content matters to the learners also. Shomoossi et al. (2008) found that interactions pattern are gender-related and only exist to some extent which requires further clarification in this study. Eriba and Achor (2010) add further that the sex of teacher in a particular classroom does matter but the present study is focused on the gender of the learners.

Physics curriculum has many concepts that students find difficult to learn. Oyelami (2010) maintains that difficult physics concepts are not only at secondary school level but also at tertiary level. The National Examination Council (NECO) as well as the West African Examination Council (WAEC/SSCE) Chief Examiners' report on students' performance (2007) indicates that students find some physics concepts difficult to understand and learn and therefore perform poorly. In the same vein, SSCE/WAEC (2011, $2012 \& 2013)$ and SSCE/NECO (2011, 2012 \& 2013) Chief Examiners' report show that lack of understanding of fundamental concepts of physics contributed to the abysmal performance of students in physics examinations. According to Ivowi (1999) and Njoku (2005) the difficult physics concepts include waves, light waves, sound waves, electricity, magnetism, nuclear physics, measurement of heat energy, vectors, pressure and simple harmonic. Checkley (2010); Ornek et al. (2008) and Erinosho (2013) identified the following difficult concepts in physics: energy quantization, AC circuit, projectile motion, electric field and simple harmonic motion. Going by the list presented from these numerous studies, simple harmonic motion and projectile are major aspects of dynamics in addition to Newton's laws and forces. The difficulty students experience in understanding physics concepts appears to cut across many countries as can be seen from previous studies (Fisher, 2009; Checkley, 2010; Obafemi and Onwioduokit, 2013; Ogunleye, 2013).

In Nigeria, the general attitude of people towards the teaching profession is negative (Piwuna and Mang, 2005; Achor and Orji, 2009) and worse towards science teaching and learning. This negative attitude has been subtly deposited into the fertile minds of the younger generation especially those in the secondary schools resulting in loss of interest for science learning. Attitudes are inclinations and predispositions that guide an individual's behaviour and persuade him to take an action that can be evaluated as either positive or negative (Robinstein, 1986). Attitudes also develop and change with time. Attitudes may be formed from direct personal experience or they may result from observation. Social roles and social norms can have a strong influence on attitudes. From study conducted by Gyuse et al. (2016) mentoring had significant effect on the attitude of science teachers exposed to it. However, male teachers experienced greater change in attitude after mentoring compared with female teachers though this was not statistically significant. Though the study by Gyuse et al was in a mentoring situation, there are reasons to speculate that similar situation may prevail in the present study. Therefore this study examined the effects of teacher-centered and student-centered interaction practices on students' achievement and attitude in dynamics, an aspect of physics considered abstract at the secondary school level.

\section{Theoretical Framework}

The socio-cultural theory by Vygotsky (1996) provides a convincing framework for this study. This theory stipulates that learning which can take place in interaction with a more knowledgeable adult or peer is seen as first 
occurring on an inter-mental plane and then gradually turning on to the students' inter-mental level of understanding. This dialogue which occurs in an interactive situation is seen as an important means through which the external social plane is internalized by the students to assist their own thinking.

Closely related to socio-cultural theory is heuristic theory by Biddulph and Osborn (1984). This theory is concerned with the students taking responsibility for the extent and the validity of their knowledge in an interactive teaching environment. This theory has been developed in the context of physics education and involves five sequential components.

During the first stage, a topic for investigation is selected by the teacher-which should be an area in which the students have current concern and interest. It should also be an area in which it is possible for students to carry out simple practical investigation. The second stage involves the teacher encouraging the students to think and talk about the topic. The student in this stage may engage in exploratory activities, observing, recording and finding relevant points in the topic under investigation. The third stage involves the teacher identifying the questions which the students would like the teacher to answer about the topic. These questions are developed and clarified so that they can form the basis for serious investigation. The fourth stage involves the students developing the plans for carrying out investigation and gathering information to answer their questions. The role of the teacher here is to guide the students to reflect on their plans and to consider alternative ways for carrying out their investigations. The fifth and the final stage involve the teacher and students reflecting together on the results of the investigations and on the whole process. Hearteld (2001) stats that better students' achievement and attitude on a variety of outcome measures were found consistently in classes perceived as having greater teacherstudent interaction and goal direction and less tutorial and friction. These steps are strongly linked in Flander's Interaction Analysis Categorization used in this study whereby learners ask questions, find alternative ways through their answers and reflect on their plan. This process too would likely generate active interaction in the classroom.

Similar to socio-cultural theory is the Constructivist Learning theory (CLT). CLT advocates do not limit the mental creations of the students to simple replication of those held by a static scientific community or culture. Rather than being transmitted, knowledge is seen to evolve and to expand, with each new generation of "knowers". The intent of instruction in this paradigm is to give students enough support or scaffolding. Griffin and Cole (1984) said that within the zone of proximal developments (ZPP), the learners in the future may be able to attain the higher levels of conceptual hierarchies on their own. According to Griffin and Cole (1984) students who participate in the activity of the community such as a classroom, acquire a "social identity kit" which includes not only literacy and ways of thinking about subject matter but also beliefs, values and attitudes.

\subsection{Research Questions}

The following research questions were answered:

1. What is the effect of teacher-centred and student-centred classroom interactions on students' performance in dynamics in physics?

2. What is the effect of teacher-centred and student-centred classroom interaction on students' attitude towards physics?

3. What is the effect of the use of student-centred classroom interaction on male and female students' performance in physics?

4. What is the effect of the use of student-centred classroom interaction on male and female students' attitude towards physics?

\subsection{Hypotheses}

The following null hypotheses formulated were tested in this study at 0.05 level of significance:

$\mathrm{HO}_{1} \quad$ There is no significant difference in mean performance between students taught by teachers using teachercentred and those taught using student-centred classroom interactions in physics.

$\mathrm{HO}_{2} \quad$ There is no significant difference in mean attitude towards physics between students taught by teachers using teacher-centred and those taught using student-centred classroom interactions in physics.

$\mathrm{HO}_{3}$ There is no significant difference in the mean performance of male and female students exposed to studentcentred interaction.

$\mathrm{HO}_{4}$ There is no significant difference in mean attitude towards physics between male and female students exposed to student-centred interaction.

\section{Methodology}

\subsection{Design}

The quasi-experimental design was used for the study. In particular, it is the non- randomized, pretest-post test control group design. Quasi-experimental design involves establishing cause and effect relationship. Such a design enables the production of the data to be observed under the control of the researcher in order to investigate cause and effect relationship (Emaikwu, 2012). Also another reason for the choice of the design is attributed to some administration constraints in the school and as such intact classes are used for the study. Specifically, method (type of interaction) is manipulated to see its effects on students' performance in and attitude towards physics.

\subsection{Sample}

The population of the study comprised all the 3,468 senior secondary two (SS II) physics students and 33 physics teachers in the twenty-five secondary schools in Kogi East Local Government Areas. The population is that of the SS II physics students and teachers in Kogi East Local Government Areas as at 2015/2016 academic session.

First, purposive sampling was used in identifying and selecting schools that met the following criteria:

1. Evidence of continuous presentation of candidates for external examination in Physics 
2. Availability of a qualified Physics teacher

3. Availability of a functional and well equipped laboratory

By virtue of the above criteria, four schools were purposively selected. In these schools, 139 physics students (72 males and 67 female) and seven teachers (4 did the teaching and 3 others observed the classes). A simple random sampling method was employed to select four intact classes for the study.

\subsection{Instrumentation}

Three instruments were used to obtain data for the study. These are:

1. Teacher-Student Classroom Observation Schedule (TSCOS).

2. $\quad$ Students' Attitude Questionnaire (SAQ)

3. Physics Achievement Test (PAT)

TSCOS: Flanders' Interaction Analysis Categories (FIAC) (Flanders, 1959) was used to determine interactions in classes. Specifically, the modified version by Gyuse et al. (2016) was used. Details include:

1. Direct teacher verbal behaviour

2. Indirect teacher verbal behaviour

3. Students' verbal behaviour

4. Students' non-verbal behaviour

5. Teachers' non-verbal behaviour

6. Silence (Non functional verbal behaviour)

7. Confusion \& Irrelevant behaviour

The instrument assumed that all interactions in classroom could be grouped into these 7 major categories which are all measured by one form of act of verbal or non verbal expression or the other.

The observation data were collected using FIAC from four classes; each taught by a sample teacher and observed by three other qualified teachers. In this way 12 sets of observations data were obtained. During the data collection, the following rules as recommended by Flander were followed. There are 14 ground rules put in place by Flander to help in developing consistency in trying to categorize teacher behaviour. The rules, which were adapted in this study, are available in most FIAC documents for consultation. These rules include:

1. When not certain to which two or more categories a statement belongs, choose the category that is numerically farthest from category 5 .

2. If the primary tone of the teacher's behaviour has been consistently direct or consistently indirect, do not shift into the opposite classification unless a clear indication of shift is given by the teacher.

3. The observer must not be concerned with his own biases or with the teacher's intent, and so on.

Records of activities of the teacher and learners in the classroom including period of silence were taken every 3 seconds for a total of 35 minutes for the four classes. What was used for analysis in this study is a cumulative record of three observers per class giving a total of 12 observations. The observers were trained on how to make observations during science classroom interaction using Flander's Interaction Analysis Categorisation instrument. The observers used pre-prepared tally sheets for records. Each observation took a tally sheet. At the end, the records from the 12 tally sheets for the 12 observations were collated.

An intra-observers' reliability was estimated using Scott's phi-coefficient formula. The reliability of the two teachers' coding was found to be 0.68. Since there are 7 unit items of observation on modified FIAC, a 7 by 7 matrix was developed (first 7 is for number of observations on the vertical and the second 7 is number of possible observations on the horizontal). Frequency of observations was used for analysis in this study since it was for categorization only.

The actual teaching in the four classes commenced after a pretest. It lasted for 6 weeks and was immediately followed by a post test.

SAQ: This questionnaire was used to obtain information about students' attitude towards physics. The questionnaire has two sections: $\mathrm{A}$ and $\mathrm{B}$.

Section A sought to know the personal data of the students. The information required included the name of school, gender and age.

Section B consisted of 22 items to measure the attitudes of students towards physics.

The subjects were required to indicate the degree of agreement or disagreement with each of the statement in a 5-point Likert scale of Strongly Agree (SA), Agree (A), Undecided (U), Disagree (D), and Strongly Disagree (SD). The scores assigned to the responses are:

$\begin{array}{lll}\text { - } & \text { Strongly Agree } & (5) \\ \text { - } & \text { Agree } & (4) \\ \text { - } & \text { Undecided } & (3) \\ \text { - } & \text { Disagree } & (2) \\ \text { - } & \text { Strongly Disagree } & (1)\end{array}$

For those response that required SD as the most desired response and $\mathrm{A}$ as the least desired response scores shall be reversed as $\mathrm{SA}=1$ to $\mathrm{SD}=5$. Most items in SAQ were adapted from Test of Science Related Attitudes (TOSTRA) developed by Frasher (1981). The reliability of SAQ is 0.86 using Cronbach's Alpha.

PAT: The instrument is made up of two parts; section A is the demographic information while section $\mathrm{B}$ consists of multiple choice test made up of initial 30 items with four options (a-d) for the students to answer all.

The PAT was administered twice i.e before (pre) and after (post) the experiment. The pre-PAT was used to ascertain the level of performance in dynamics in physics. The post-PAT (which is the reshuffled form of prePAT in terms of position of items and correct options) was used to determine the extent of students' physics 
performance after the experiment. The content of PAT is based on the senior secondary two physics curriculum that contained the following topics:

a. Speed, velocity and acceleration

b. Newton's law of motion

c. Force, power and work

d. Distance time graphs, velocity time graph,

e. Introductory projectiles

f. Simple harmonic motion

Consideration was given to the behavioural objectives of the content taught in the lesson plan as they serve as a guide in determining the number of items per topic for each of the units studied. The items were selected to cover lower and higher order cognitive levels of Blooms' taxonomy of educational objectives'. A table of specification was used to determine the number of items in different cognitive ability levels and topics. Using Kuder Richardson 21 , the reliability of PAT was determined to be 0.79 .

\section{Results}

The first procedure in the study was the observation which was undertaken to determine the kind of interaction in physics classrooms under investigation. This was intended to enable the researchers classify the classes under teacher-centred and student-centred classes. After visiting many classes, four patterns of interactions were distinctive. These were then grouped into two classes for teacher-centred and two others for student-centred interactions. Table 1 and Figure 1 explain this clearly.

Table-1. Interactions in Student-Centred and Teacher-Centred Physics Classes.

\begin{tabular}{l|c|c}
\hline Category of Interaction & Teacher-Centred & Student-Centred \\
\hline Indirect teacher verbal behaviour & 402 & 230 \\
\hline Direct teacher verbal behavior & 425 & 317 \\
\hline Students' verbal behavior & 174 & 181 \\
\hline Students' non-verbal behavior & 181 & 392 \\
\hline Teachers' non-verbal behavior & 183 & 280 \\
\hline Silence (Non functional verbal behaviour) & 18 & 16 \\
\hline Confusion \& Irrelevant behaviour & 11 & 1428 \\
\hline Total & 1394 & \\
\hline Source: Field Work 2016. &
\end{tabular}

Source: Field Work 2016.

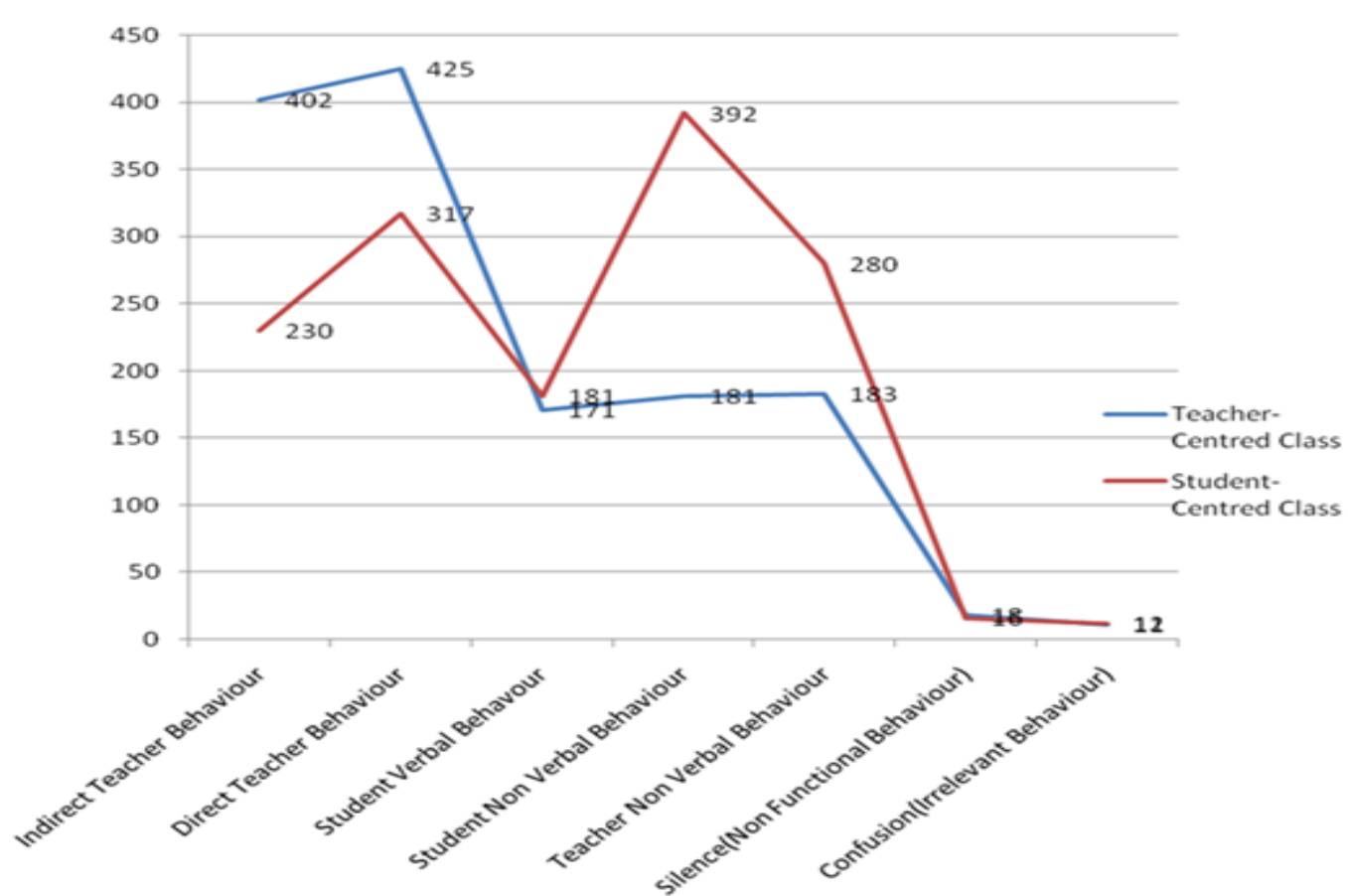

Figure-1. Categorisation of Classes into Teacher-Centred and Student-Centred Interaction Classes. Source: Field Work 2016.

From Table 1 and Figure 1, the categorization is based on where much time is spent during the lesson or simply put, the activities carried out as part of the lesson. Accordingly classes that spent high time in teacher directed behaviour were said to be teacher-centred while those that spent more time in student behaviour and teacher non verbal behaviour were said to be student-centred classes. Figure 1 shows this clearly. The graphs indicate area of more time: teacher directed behaviour for teacher-centred and student behaviour and teacher non verbal behaviour for student-centred interactions. These now became the groups used for the experiment to determine effects on performance and attitude of the students.

Table 2 and Figure 2 addressed research question 1. 
Table-2. Mean and Standard Deviation Scores of Students' Performance in Teacher-Centred and Student Centerd Classes in Physics.

\begin{tabular}{c|c|c|c|c}
\hline \multicolumn{2}{c}{ Interaction Type } & Pre PAT & Post PAT & Mean Gain \\
\hline \multirow{2}{*}{ Teacher-Centred Classroom Interaction } & Mean & 8.5789 & 15.4342 & 6.86 \\
\cline { 2 - 5 } & $\mathrm{N}$ & 76 & 76 & 4.97282 \\
\cline { 2 - 5 } & Std. Deviation & 2.51536 & 63 & 5.41551 \\
\cline { 2 - 5 } & N & 63 & 18.6508 & 8.46 \\
\cline { 2 - 5 } & Std. Deviation & 3.09452 & & 1.60 \\
\hline Student-Centred Classroom Interaction & Mean & 10.1905 & & \\
\hline Mean difference & & &
\end{tabular}

Source: Field Work 2016

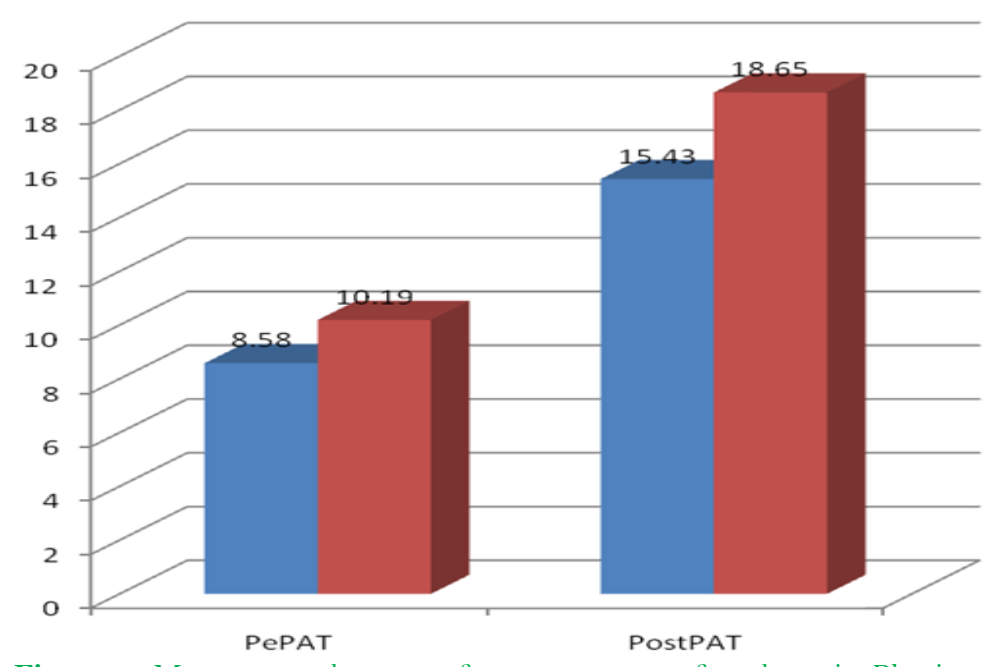

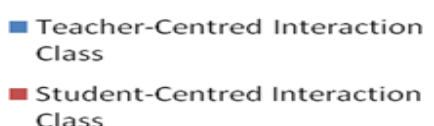

Class

Figure-2. Mean pre and post performance scores of students in Physics Achievement Test (PAT) for teacher centred and student-centred classroom interactions.

Source: Field Work 2016

Table 2 shows the mean and standard deviation scores of students' performance in teacher-centred and student-centred classroom interaction practices in physics. The table reveals a mean gain score of 6.86 for teachercentred class and 8.46 for student-centred class with a mean difference of 1.60 in favour of student-centred classroom interaction. The mean performance for the two groups at pre and post tests are shown clearly in Figure 2.This means that students who were in student-centred classroom gained more knowledge of dynamics aspect of physics than those in the teacher-centred class. The fact that the students were actively involved in the lesson must have accounted for the difference in mean for the student-centred class.

Table 3 and Figure 3 addressed the research question 2.

Table-3. Mean and Standard Deviation Scores of Students' Attitude in Teacher-Centred and Student Centerd Classes in Physics.

\begin{tabular}{c|c|c|c|c}
\hline \multicolumn{2}{c|}{ Interaction Type } & Pre SAQ & Post SAQ & Mean gain \\
\hline \multirow{2}{*}{ Teacher-Centred Classroom Interaction } & Mean & 2.8157 & 3.3110 & 0.50 \\
\cline { 2 - 5 } & $\mathrm{N}$ & 76 & 76 & .11404 \\
\cline { 2 - 5 } & Std. Deviation & .27591 & 3.1919 & 0.56 \\
\hline Student-Centred Classroom Interaction & Mean & 2.6350 & 63 & .11325 \\
\cline { 2 - 5 } & $\mathrm{N}$ & 63 & & 0.06 \\
\hline
\end{tabular}

Source: Field Work 2016

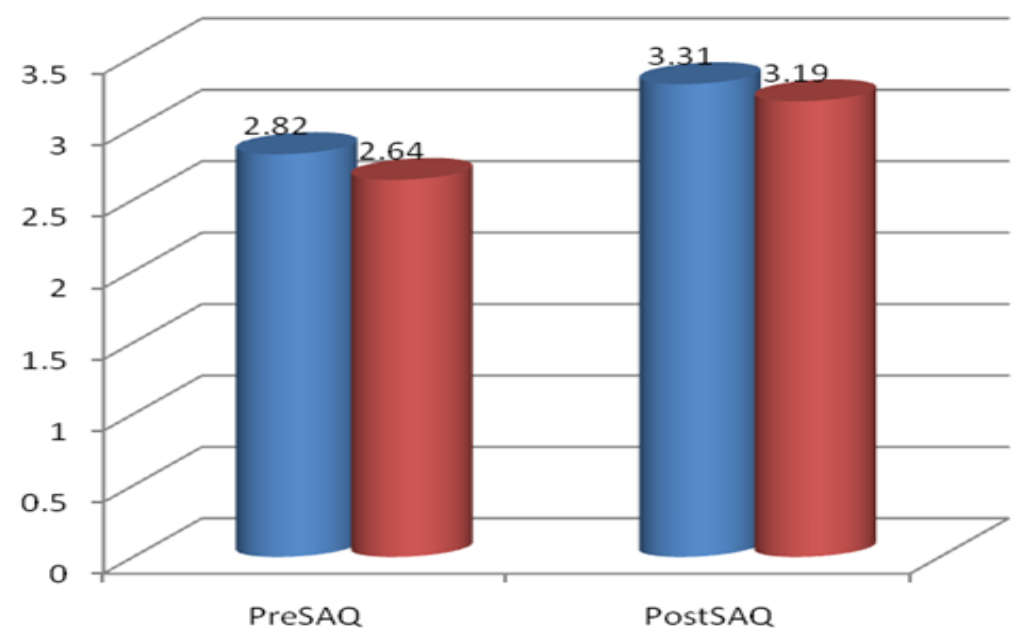

Teacher-Centred Interaction Class

- Student-Centred Interaction Class

Figure-3. Mean pre and post attitude scores for students in teacher-centred and student-centred classroom interactions. Source: Field Work 2016. 
Table 3 shows the mean and standard deviation scores of students' attitude in teacher-centred and studentcentred classroom interaction practices in physics. The table reveals a mean gain attitude score of 0.50 for teachercentred class and 0.56 for student-centred class with a mean difference of 0.06 in favour of student-centred classroom interaction. Figure 3 also shows the pre and post test mean scores for both groups. This means that students who were in student-centred classroom recorded more positive attitude to physics than those in the teacher-centred class. The fact that the students were actively involved in the lesson may have accounted for the difference in mean attitude in favour of the student-centred class.

Table 4 and Figure 4 addressed research question 3.

\begin{tabular}{|c|c|c|c|c|}
\hline \multicolumn{2}{|c|}{ Gender } & \multirow{2}{*}{$\frac{\text { Pre PAT }}{10.3438}$} & \multirow{2}{*}{$\frac{\text { Post PAT }}{19.5938}$} & \multirow{2}{*}{$\frac{\text { Mean Gain }}{9.25}$} \\
\hline Male & Mean & & & \\
\hline & $\mathrm{N}$ & 32 & 32 & \\
\hline & Std. Deviation & 3.2687 & 5.3452 & \\
\hline \multirow[t]{3}{*}{ Female } & Mean & 9.5484 & 18.0645 & 8.52 \\
\hline & $\mathrm{N}$ & 31 & 31 & \\
\hline & Std. Deviation & 2.3782 & 5.2086 & \\
\hline Mean difference & & & & 0.73 \\
\hline
\end{tabular}

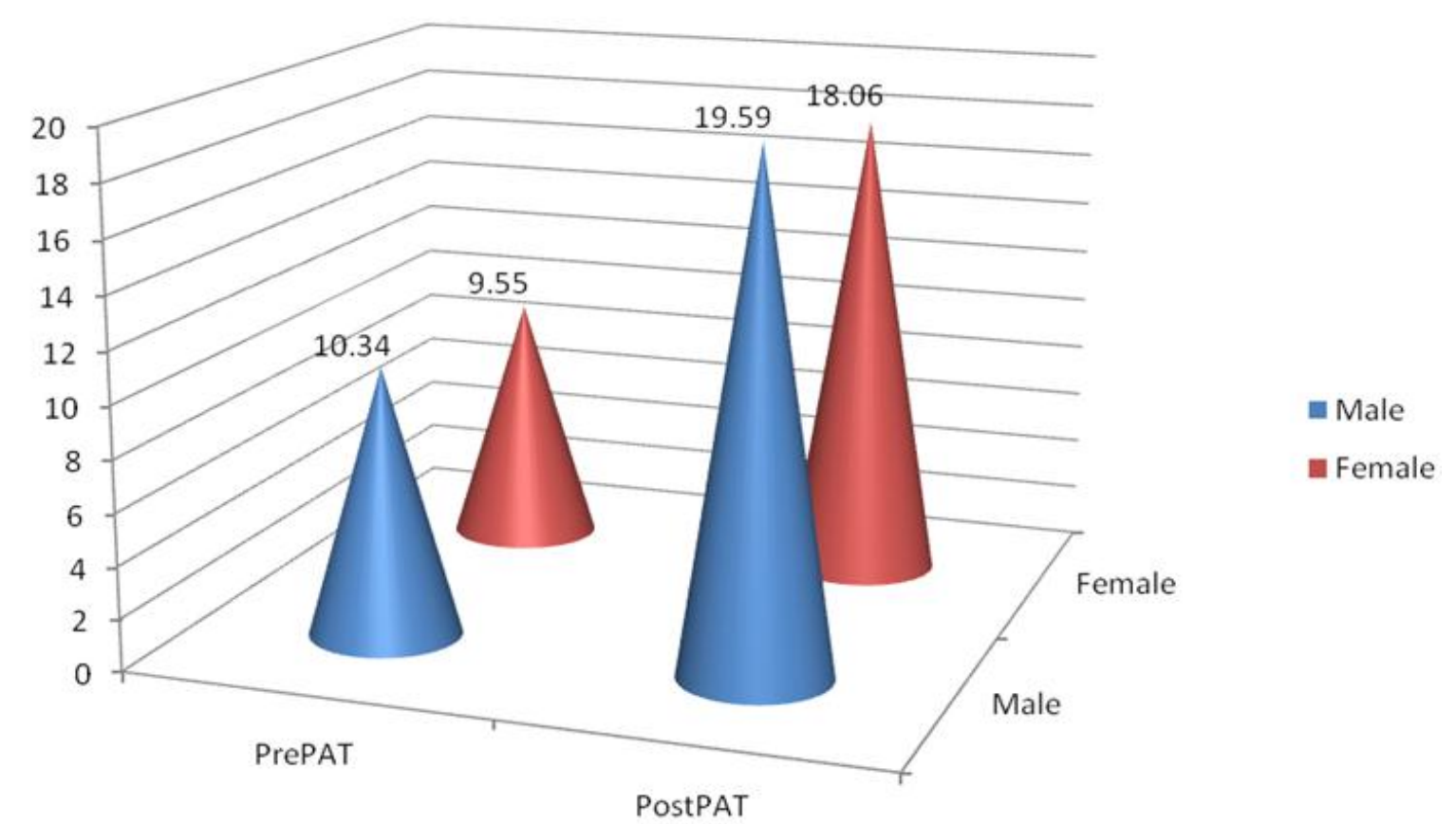

Figure-4. Mean performance scores of male and female students in student-centred classroom interaction. Source: Field Work 2016

Table 4 shows the performance of male and female students in student-centred classroom. While the male students gained 9.25, the female students gained 8.52 with a mean difference of 0.73 in favour of the male students. Again Figure 4 shows the pre and post test mean scores for male and female students in student-centred interaction classroom. By implication the male students in this study benefited more from instruction in studentcentred classroom interactions compared with the female students. However, the mean score difference of 0.73 appears small and needs to be further subjected to further statistical analysis.

Table 5 and Figure 5 are used to answer research question 4.

Table-5. Mean and standard deviation scores of male and female students' attitude in student-centered class.

\begin{tabular}{c|c|c|c|c}
\hline \multicolumn{2}{c}{ Gender } & Pre SAQ & Post SAQ & Mean Gain \\
\hline \multirow{2}{*}{ Male } & Mean & 2.7071 & 3.1903 & 0.48 \\
\cline { 2 - 5 } & $\mathrm{N}$ & 32 & 32 & \\
\cline { 2 - 5 } & Std. Deviation & .23472 & .12242 & \\
\hline \multirow{2}{*}{ Female } & Mean & 2.5606 & 3.1935 & 0.63 \\
\cline { 2 - 5 } & $\mathrm{N}$ & 31 & 31 & \\
\cline { 2 - 5 } & Std. Deviation & .20826 & .10495 & 0.15 \\
\hline
\end{tabular}

Source: Field Work 2016.

Table 5 shows the attitude of male and female students in student-centred classroom. While the males gained 0.48 , the females gained 0.63 with a mean difference of 0.15 in favour of the females. Figure 5 clearly shows pattern of performance. By implication the female students in this study gained higher positive change in attitude towards study of physics in student-centred classroom interactions compared with the males. However, the mean score difference of 0.15 in mean attitude appears small and needs to be subjected to further statistical analysis. 


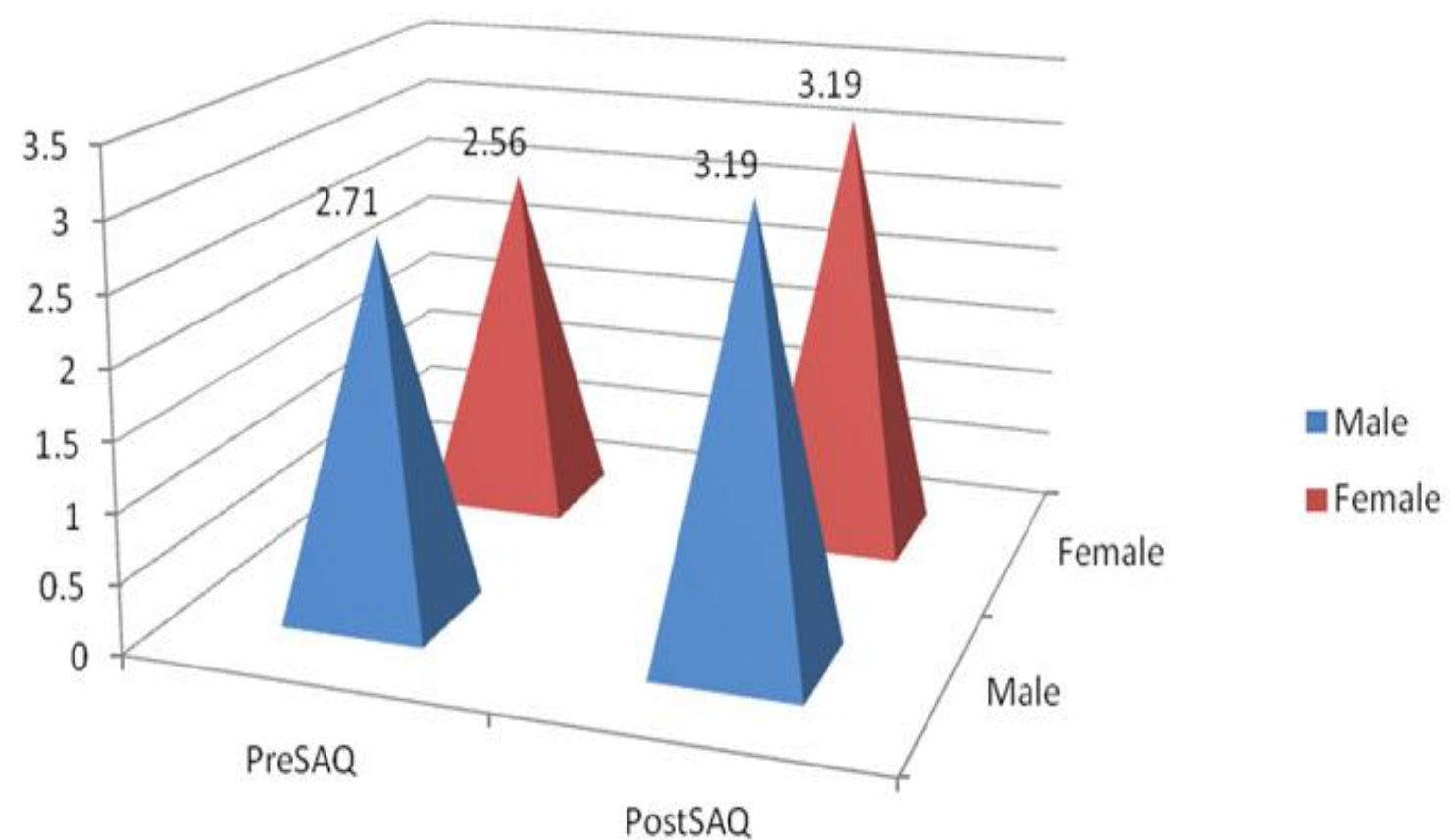

Figure-5. Mean pre and post attitude scores for male and female students in student-centred classroom interaction. Source: Field Work 2016.

Information on Table 6 are used to test hypothesis 1.

Table-6. ANCOVA Tests of Effect of Teacher Centred and Student Centred Classroom Interactions on Students' Mean Performance in Physics.

\begin{tabular}{c|c|c|c|c|c}
\hline Source & Type III Sum of Squares & df & Mean Square & F & Sig. \\
\hline Corrected Model & $454.966^{\text {a }}$ & 2 & 227.483 & 8.749 & .000 \\
\hline Intercept & 2157.320 & 1 & 2157.320 & 82.975 & .000 \\
\hline Pre PAT & 55.115 & 1 & 55.115 & 2.120 & .148 \\
\hline Interaction Type & 403.763 & 1 & 403.763 & 15.529 & .000 \\
\hline Error & 3535.969 & 136 & 26.000 & & \\
\hline Total & 44060.000 & 139 & & & \\
\hline Corrected Total & 3990.935 & 138 & & \\
\hline
\end{tabular}

a. $\quad$ R Squared $=.114$ (Adjusted R Squared $=.101)$.

Source: Field Work, 2016

Table 6 reveals that with $\mathrm{F}(1,138)=15.53, \mathrm{p}=0.00<0.05$, there is a significant difference in mean scores between students taught dynamics in teacher-centred classroom interaction and those taught in student-centred classroom interaction. The null hypothesis is therefore rejected. This means that student-centred classroom interaction enhanced performance in physics compared with students in teacher-centred classroom interaction and that the difference is statistically significant.

Data on Table 7 are used to test hypothesis 2.

Table-7. ANCOVA Tests of Effect of Teacher-Centred and Student-Centred Classroom Interactions on Students' Mean Attitude towards Physics.

\begin{tabular}{c|c|c|c|c|c}
\hline Source & Type III Sum of Squares & df & Mean Square & F & Sig. \\
\hline Corrected Model & $.499^{\mathrm{a}}$ & 2 & .250 & 19.290 & .000 \\
\hline Intercept & 12.050 & 1 & 12.050 & 931.164 & .000 \\
\hline Pre SAQ & .011 & 1 & .011 & .830 & .364 \\
\hline Interaction Type & .390 & 1 & .390 & 30.162 & .000 \\
\hline Error & 1.760 & 136 & .013 & \\
\hline Total & 1476.806 & 139 & & & \\
\hline Corrected Total & 2.259 & 138 & & & \\
\hline
\end{tabular}

a. $\quad$ R Squared $=.221$ (Adjusted R Squared $=.210$ ).

Source: Field Work, 2016.

Table 7 reveals that with $\mathrm{F}(1,138)=30.16, \mathrm{p}=0.00<0.05$, there is a significant difference in mean attitude scores between students taught dynamics in teacher centred classroom interaction and those taught in studentcentred classroom interaction. The null hypothesis is therefore rejected. This means that student-centred classroom interaction enhanced positive attitude towards physics compared with students taught physics with teacher-centred classroom interaction.

Data on Table 8 are used to test hypothesis 3. 
Table-8. ANCOVA Tests of Effect of Student-Centred Classroom Interaction on Male and Female Students' Mean Performance in Physics.

\begin{tabular}{c|c|c|c|c|c}
\hline Source & Type III Sum of Squares & df & Mean Square & F & Sig. \\
\hline Corrected Model & $42.510^{\text {a }}$ & 2 & 21.255 & .753 & .475 \\
\hline Intercept & 1479.812 & 1 & 1479.812 & 52.417 & .000 \\
\hline Pre PAT & 5.687 & 1 & 5.687 & .201 & .655 \\
\hline Gender & 32.214 & 1 & 32.214 & 1.141 & .290 \\
\hline Error & 1693.903 & 60 & 28.232 & \\
\hline Total & 24101.000 & 63 & & & \\
\hline Corrected Total & 1736.413 & 62 & & & \\
\hline
\end{tabular}

a. R Squared $=.024$ (Adjusted R Squared $=-.008)$.

Source: Field Work, 2016.

It can be seen from Table 8 that with $\mathrm{F}(1,62)=1.14, \mathrm{p}=0.29>0.05$, there is no significant difference between the mean performance scores of male and female students exposed to student-centred classroom interaction. The null hypothesis is therefore not rejected. This means that the class is either very interactive to an extent that both male and female student equally enjoyed and understood the lesson at near equal level or that the topics are still abstract to them.

Information on Table 9 are used to test hypothesis 4 .

Table-9. ANCOVA Tests of Effect of Student-Centred Classroom Interaction on Male and Female Students' Mean Attitude towards Physics

\begin{tabular}{c|c|c|c|c|c}
\hline Source & Type III Sum of Squares & df & Mean Square & F & Sig. \\
\hline Corrected Model & $.014^{\mathrm{a}}$ & 2 & .007 & .524 & .595 \\
\hline Intercept & 3.917 & 1 & 3.917 & 300.738 & .000 \\
\hline Pre SAQ & .013 & 1 & .013 & 1.036 & .313 \\
\hline Gender & .002 & 1 & .002 & .184 & .669 \\
\hline Error & .782 & 60 & .013 & \\
\hline Total & 642.661 & 63 & & \\
\hline Corrected Total & .795 & 62 & & & \\
\hline
\end{tabular}

a. R Squared $=.017$ (Adjusted R Squared $=-.016$ ).

Source: Field Work, 2016

It can be seen from Table 9 that with $\mathrm{F}(1,62)=0.18, \mathrm{p}=0.67>0.05$, there is no significant difference between the mean physics attitude scores of male and female students exposed to student-centred classroom interaction. The null hypothesis is therefore not rejected. This means that the class was interactive to an extent that both male and female students equally enjoyed and understood the lesson at near equal level.

\section{Discussion of Findings}

One of the findings in this study is that student in student-centred type of classroom interaction gained more knowledge of dynamics aspect of physics than those in the teacher-centred class. The fact that the students were actively involved in the lesson must have accounted for the difference in mean for the student-centred class. Further, there is a significant difference in mean scores between students taught dynamics in teacher-centred classroom interaction and those taught in student-centred classroom interaction. The teacher in the studentcentred classroom interaction made use of some innovative, learner oriented strategies giving room to students to ask question, answer questions and seek clarification. In essence, teachers in this group made use of learner participatory strategies. The classes were very interactive with the students involved in doing. On the other hand, teacher-centred classes were dominated with the use of expository method spiced with demonstration. Students were less engaged and so they were not active in the class. This finding is in agreement with that of Foley and Mcphee (2008) who in a comparative study on the impact of interaction and traditional teaching method on students' achievement in chemistry in selected secondary schools in Ghana using hands-on as interaction method found that all students' rating on a 5 point scale showed hands-on average to 4.33 for all students compared to lecture (3.34), project (3.97) and demonstration (3.98). Students in the hands-on classes rated interaction higher (4.44) than in traditional teaching method classes (4.23). The finding is also in agreement with that of Owodunni (2015) who found that persistent poor students' achievement in Basic Electricity could be attributed to teachers' inability to look at classroom interaction patterns in the context of teaching. This is because with the use of this variable as main influence in this study, performance of students improved significantly.

The student-student interaction pattern or discussion pattern promotes co-operative learning in which participants strive for mutual benefits among group members (Anekwe, 2006; Okoli, 2006). The students under this learning encounter work collaboratively in order to seek solution to a common problem by supporting each other. The low ability level students in the group were helped to improve through interactions with the other colleagues that were brighter. This could account for the observed improved achievement of students' in dynamics. The student-student learning/discussion incorporates the elements of listening, talking, questioning, responding, reflecting, exchanging viewpoints, debating, writing answers and comments to questions and reading assignments for class discussion. Hence, students learn through social interaction which is a powerful learning tool in the educational system. The finding that students' mean performance scores in dynamics were significantly influenced by classroom interaction patterns is in agreement with the findings of Okoli (2006) and Anekwe (2006) that two interaction learning styles, co-operative and competitive strategies significantly enhanced students' achievement in Basic Electricity and chemistry, than conventional learning styles. The result 
also agreed with Kalu (2004) that classroom interaction patterns correlated significantly with students' academic achievement in physics.

Students who were in student-centred classroom recorded more positive attitude to physics than those in the teacher-centred class. There is a significant difference in mean attitude scores between students taught dynamics in teacher-centred classroom interaction and those taught in student-centred classroom interaction. Thus, studentcentred strategy influenced students' attitude positively over a relatively short period. Since the students themselves were actively involved in the lesson where they asked as well as answered questions to clear doubts and, possibly, make inputs, it was expected that they will display an improved attitude towards the study of physics. This aspect was considered necessary as previous studies point to the fact that both poor performance and low enrolment are prevalent in physics at the secondary school level. In agreement with this finding, Adesoji (2008) ran a survey on managing students' attitude towards science through problem-solving interaction strategy and found that the attitude of the student towards chemistry was positive, which infers that the problem-solving technique was more interesting to students. The implication of this is that an interactive strategy of classroom leads to improved attitude to study and towards the subject.

Another finding is that there is no significant difference between the mean performance scores of male and female students exposed to student-centred classroom interaction. Also, there is no significant difference between the mean physics attitude scores of male and female students exposed to student-centred classroom interaction. These two findings seem to be similar. If a strategy is exciting and most students actively participate in the lesson, gaps in performance and attitude will be bridged reasonably. This is inconsistent with the results of Shomoossi et al. (2008); Rashidi and Naderi (2012) study which indicated that in classroom interaction boys are more likely than girls to create conditions where their contributions will be sought by teachers, and that they are more likely than girls to push themselves forward when contributors are not explicitly selected. This of course could influence attitude and performance positively.

\subsection{Implications of the Findings for Teaching-Skill Development for Physics Teachers}

The findings of the present study have a lot of implications for Physics teachers. The fact that student-centred interaction facilitated learning outcomes in Physics classrooms further gives empirical credence to the influence of classroom environment in the overall academic activities of students. Again, the results of the study implied that student-centred interaction practices could be used to address the persistent report of poor performance and low enrolment which deserves urgent attention. It is equally, on record, that communication contributes to effective teaching in classrooms; however, the findings of the present study has shown that it is the style and direction of communication that make the communicative interactions very efficacious especially in enhancing learning outcomes (that is, attitude and performance) among secondary school students. It is therefore recommended that Physics teachers should try to make their lessons more interactive and learner-participatory.

The findings again point to the fact that the future of physics study still lies with the teacher. There is need to go back to the drawing board and train the teachers in the skill of lesson presentation which could be reflected in the answers to such questions as: When and how will the learners participate in lessons? When do I allow them ask their questions and answer my own questions? And how could I deliver my lesson without dominating the class? These are considered teaching skills that are very relevant to physics teachers. A physics classroom should be carefully guided to become a place of lively interactions which should not be lop-sided in favour of the teacher.

On this premise, therefore, it is expected that pre-service physics teachers should be trained to be very skillful in facilitating learning outcomes through student-centred interaction practices. This is considered a necessary step in skill development among physics teachers.

\section{Conclusion}

This study has established that student-centred kind of classroom interaction facilitates students' performance in physics and was as well effective in changing students' attitude towards physics. However student-centred classroom interaction is gender-friendly and thus both male and female students had similar and good learning outcomes (that is, performance and attitude). However, teacher-centred classroom interaction pattern poorly facilitated performance and had less impact on students' attitude.

\section{Recommendations}

The findings of this study and the conclusion drawn informed the following recommendations:

1. Physics teachers in training should be exposed to teaching strategies that lay emphasis on type of interaction in the classroom especially the student-centred classroom interaction. In so doing, care should be taken on time allotment to avoid the teacher dominating the class.

2. There is need to make the learners excited in what they learn and this could be made possible from making them develop positive attitude. Student-centred classroom interaction could be used by physics teacher to improve their attitude towards learning of physics and thereby become excited learners in physics.

3. When gender balance in performance and attitude is needed student-centred classroom interaction is recommended for use as it eliminates differences in performance and attitude by engaging both genders actively during the lesson.

\section{References}

Achor, E.E. and A. Orji, 2009. Level of students' motivation in classroom interactions in integrated science. Journal of Research in Curriculum and Teaching, 4(1): 294-303.

Adesoji, F.A., 2008. Managing students' attitude towards science through problem solving instructional strategy. Anthropologist, 10(1): 2124.

Ajagun, G.A., 2007. Towards good performance in science education: In E. J. Maduewesi (Ed). Nigerian Journal of Teacher Education and Teaching, 2(1): 117-125.

Anekwe, M., 2006. The effects of students' interaction patterns on cognitive achievement retention and interest in Chemistry in Anambra State. Unpublished Ph.D Thesis, University of Nigeria, Nsukka. 
Audu, T. and E. Achor, 2003. The role of questioning and wait-time interactional processes in science teaching and learning. Journal of Science and Vocational Education, 2(2): 53-56.

Biddulph, E. and W. Osborn, 1984. When talking doesn't help: An investigation of microcomputer group problem solving. Learning and Instruction, 2(3): 123-128.

Checkley, D., 2010. High school students' perception of Physics. An Unpublished Master of Education Thesis Submitted to the School of Post-graduate Studies, University of Lethbridge.

Emaikwu, S.O., 2012. Fundamentals of research methods and statistics. Makurdi: Selfers Academic Press Ltd.

Eriba, J. and E.E. Achor, 2010. Effects of school type and teacher gender on classroom interaction patterns in integrated science classes. Brunei International Journal of Science and Mathematics Education, 2(1): 48-58.

Erinosho, S.Y., 2013. How do students perceive the difficulty of physics in secondary school? An exploratory study in Nigeria. International Journal for Cross-disciplinary Subjects in Education, 3(3): 1510-1515.Available at: https://doi.org/10.20533/ijcdse.2042.6364.2013.0212.

Fisher, N.J., 2009. Identification and examination of physics concepts that students find most difficult. Available from http://www.percentral.org/items/detaikl.cfm [Accessed 22/10/2016].

Flanders, N.A., 1959. Analyzing teaching behaviour. Reading. Massachusetts: Addison-Wesley Publishing Company.

Foley, J.B. and M. Mcphee, 2008. Students attitude towards science in classes using hands-on or textbook based curriculum. Paper Presented at the Meeting of The American Educational Research Association, New York.

Frasher, B.J., 1981. Test of science related attitudes. Australia: Macquarie University Pub.

Freedman, M.P., 1997. Relationship among laboratory instruction, attitude toward science, and achievement in science knowledge. Journal of Research in Science Teaching: The Official Journal of the National Association for Research in Science Teaching, 34(4): 343-357.

Griffin, P. and M. Cole, 1984. Current activity for the future: The Zo-ped. In B. Rogoff \& J. Wertsh (Eds), Children’s learning in the Zone of proximal development. San Francisco: Jossey-Bass, pp: 45-64.

Gyuse, E., J. Eriba, R. Samba and E.E. Achor, 2016. Peer mentoring as intervention strategy towards improving secondary teachers' interaction and attitude in secondary schools. Journal of Scientific Research \& Reports, 10(7): 1-25.Available at: https://doi.org/10.9734/jsrr/2016/24750.

Hearteld, S.S., 2001. An investigation of personality classroom interaction and student evaluations. Journal of Research in Science Teaching, 11:212-216.

Ivowi, U.M.O., 1999. Achievement level in understanding Physics concepts in secondary schools. In B. Akpan (Ed), Perspectives of education and science teaching. From the eyes of Uduogie Ivowi. Abuja: Foremost Educational Services, pp: 669-678.

Kalu, A., 2004. Classroom interaction patterns, teacher and student characteristics and students' learning outcome in Physics. Journal of Classroom Interaction, 39(2): 24-31.

National Examination Council (NECO), 2007. Facts about the National Examination Council (NECO). Minna, Nigeria: NECO Pub.

Njoku, Z., 2005. Edification and analysis of topics which teachers perceive difficult to teach in the primary science curriculum. Journal of Science Teachers Association of Nigeria, 4O(1): 11-20.

Obafemi, D. and F. Onwioduokit, 2013. Identification of difficult concepts in senior secondary school two (SS2) Physics curriculum in rivers State, Nigeria. Asian Journal of Education and e-learning, 1(5): 317-322.

Ogunleye, A.O., 2013. Teachers and students perceptions of students problem solving difficulties in physics: Implications for remediation. Journal of College Teaching and Learning, 6(7): 785-796.

Okoli, J., 2006. Effects of investigative laboratory approach and expository method on acquisition of science process skills by Biology students of different levels of scientific literacy. Journal of science teachers association of Nigeria, 41(2): 79-88.

Ornek, F., W.R. Robinson and M.P. Haugan, 2008. What makes physics difficult? International Journal of Environmental and Science Education, 3(1): 30-34.

Owodunni, A.S., 2015. Influence of classroom interaction patterns on student achievement in Basic Electricity at Technical Colleges in Federal Capital Territory, Abuja. International Conference on 21st Century Education at HCT Dubai Men's College, UAE November 2015, 7(1), 114-153.

Oyelami, B.O., 2010. Teaching difficult concepts in Physics at tertiary education level. A Paper Presented at a Conference on Capacity Building Workshop for Mathematical Sciences Lecturers in Tertiary institution organized by National Mathematics centre Abuja, Nigeria 21 st - 26th June, 2010.

Piwuna, C.N. and G.L. Mang, 2005. The necessity of attitudinal orientation for remedial science students placed in the department of science and technology education. Proceedings of Science Teachers Association of Nigeria Annual Conference. Ibadan: Heinemann Pub. pp: 288.

Rashidi, N. and S. Naderi, 2012. The effect of gender on the patterns of classroom interaction. Education, 2(3): 30-36.

Robinstein, R.A., 1986. Interdisciplinary background of community psychology: The early roots of an ecological perspective. A merican Psychological Association of Division of Community Psychology, Newsletter, 18(3): 10-14.

Shomoossi, N., M. Amouzadeh and S. Ketabi, 2008. Classroom interaction mediated by gender and technology: The language laboratory course. Novitas-ROYAL, 2(2): 176-184.

SSCE/NECO, 2011, 2012 \& 2013. NECO chief examiners' report. Abuja: NECO Pub.

SSCE/WAEC, 2011,2012 \& 2013. WAEC chief examiners' report. Abuja: WAEC Pub.

Vygotsky, L.S., 1996. Mind in society: The development of higher psychological process. Cambridge M.A: Harvard University Press.

West Africa Examination Council (WAEC), 2007. West African annual report, Lagos: West Africa Book Publishers Limited Lagos.

Asian Online Journal Publishing Group is not responsible or answerable for any loss, damage or liability, etc. caused in relation to/arising out of the use of the content. Any queries should be directed to the corresponding author of the article. 